\title{
CCN3 and bone marrow cells
}

\author{
Ken-ichi Katsube • Saki Ichikawa • Yuko Katsuki • \\ Tasuku Kihara • Masanori Terai • Lester F. Lau • \\ Yoshihiro Tamamura • Shin'ichi Takeda • \\ Akihiro Umezawa • Kei Sakamoto • Akira Yamaguchi
}

Received: 18 February 2009 / Accepted: 23 June 2009 /Published online: 23 July 2009

(C) The Author(s) 2009. This article is published with open access at Springerlink.com

\author{
Abstract CCN3 expression was observed in a broad \\ variety of tissues from the early stage of development. \\ However, a kind of loss of function in mice (CCN3 del \\ VWC domain -/-) demonstrated mild abnormality, which \\ indicates that $\mathrm{CCN} 3$ may not be critical for the normal \\ K.-i. Katsube $(\bowtie) \cdot$ S. Ichikawa $\cdot$ Y. Tamamura $\cdot$ K. Sakamoto $\cdot$ \\ A. Yamaguchi \\ Oral Pathology, Graduate School of Medical and Dental Sciences, \\ Tokyo Medical and Dental University, \\ 1-5-45 Yushima, Bunkyo-ku, \\ Tokyo 113-8549, Japan \\ e-mail: ken-tmd@umin.ac.jp \\ Y. Katsuki • T. Kihara \\ Maxillofacial Surgery, Graduate School of Medical and Dental \\ Sciences, Tokyo Medical and Dental University, \\ 1-5-45 Yushima, Bunkyo-ku, \\ Tokyo 113-8549, Japan \\ M. Terai $\cdot$ A. Umezawa \\ Department of Reproductive Biology, \\ National Institute for Child Health and Development, \\ 2-10-1 Okura, Setagaya-ku, \\ Tokyo 157-8535, Japan \\ L. F. Lau \\ Department of Molecular Genetics, \\ University of Illinois at Chicago, \\ Chicago, IL 60607-7170, USA \\ S. Takeda \\ Department of Molecular Therapy, \\ National Institute of Neuroscience, \\ Ogawa-Higashi-cho, Kodaira, \\ Tokyo, Japan \\ Present Address: \\ S. Ichikawa \\ Terumo, \\ 2-44-1Hatagaya, Shibuya-ku, \\ Tokyo, Japan
}

embryogenesis as a single gene. The importance of CCN3 in bone marrow environment becomes to be recognized by the studies of hematopoietic stem cells and Chronic Myeloid Leukemia cells. CCN3 expression in bone marrow has been denied by several investigations, but we found CCN3 positive stromal and hematopoietic cells at bone extremities with a new antibody although they are a very few populations. We investigated the expression pattern of $\mathrm{CCN} 3$ in the cultured bone marrow derived mesenchymal stem cells and found its preference for osteogenic differentiation. From the analyses of in vitro experiment using an osteogenic mesenchymal stem cell line, Kusa-A1, we found that $\mathrm{CCN} 3$ downregulates osteogenesis by two different pathways; suppression of BMP and stimulation of Notch. Secreted CCN3 from Kusa cells inhibited the differentiation of osteoblasts in separate culture, which indicates the paracrine manner of $\mathrm{CCN} 3$ activity. $\mathrm{CCN} 3$ may also affect the extracellular environment of the niche for hematopoietic stem cells.

Keywords Nov · Notch · Stem cells · Niche · Hematopoiesis · Osteogenesis

\section{Introduction}

CCN3 (Nov, Nephroblastoma overexpressed) was originally identified as a gene that is responsible for nephroblastoma in chicken induced by the infection of a retrovirus (Soret et al. 1989) and now classified as a member of CCN family of genes (Brigstock et al. 2003). CCN is a Cysteine-rich small secretory protein that interacts with various extracellular and transmembrane proteins. In chicken embryogenesis, CCN3 expression starts from the early stage (Hamburger and Hamilton (HH) Stage 5) (Katsube et al. 2001). Initial 
CCN3 expression was observed in the axial structure complex (notochord and floor plate), which guides the polarized differentiation of midline structure from the ventral side, such as neural tube, vertebra, and visceral endoderm. Since this body patterning stage, CCN3 expression is observed in a wide variety of mesodermal and ectodermal cells such as osteoblasts, myoblasts, chondroblasts, epithelial cells and neuroblasts. Even in adult, several mesodermal tissues maintain the expression of CCN3. Like $C C N 3, C C N 1$ and $C C N 2$ expression was observed in mesodermal tissues from the early stage development (Katsube et al. 2009), but their pattern is not identical. CCN1 expression during development is observed in extraembryonic tissues such as the chorion and the allantois during the placenta formation (Mo et al. 2002). CCN2 expression was observed in the developing notochord (Chiou et al. 2006; Erwin 2008), but its pattern is not precisely the same as $C C N 3$.

The broad distribution of CCN3 in embryonic tissues let us expect drastic deformities in its knockout mice, but a recent investigation about a practical $C C N 3$ knockout mice (CCN3 del VWC domain -/-) revealed that they are viable even after the birth (Heath et al. 2008). Although several mild changes in skeletogenesis and joint formation, myocardiopathy and lens degeneration of eye were found, whole morphogenesis is not much affected. CCN3 is not likely to be really critical as a single gene in the normal step of embryogenesis although there is an argument if this $\mathrm{KO}$ mice really represent a true loss of function of $\mathrm{CCN} 3$ (Perbal 2007). This fact is rather surprising because dysmorphic changes in both CCN1 and CCN2 knockout mice were apparent in the vasculogenesis and osteo/ chondrogenesis, which lead to the lethal hemorrhage or skeletal abnormalities before or just after the birth(Mo et al. 2002) (Ivkovic et al. 2003).

The role of $\mathrm{CCN} 3$ in adult tissues remains elucidated, but several investigations suggest the role of $\mathrm{CCN} 3$ in hematopoiesis. Chronic myeloid leukemia (CML) occurs by a chromosomal translocation of $\mathrm{t}(9 ; 22)(\mathrm{q} 34 ; \mathrm{q} 11)$, which creates a fused protein between BCR and ABL, a constitutively active form of tyrosine kinase. Before the stage of acute blastic crisis, the growth of CML cells requires the niche environment of hematopoiesis although they partially obtain the cell autonomous proliferation ability. The mechanism of acute blastic crisis is not yet fully understood, but initial potency of CML is believed to be due to the constitutive kinase activation of BCR-ABL gene product. Down-regulation of $\mathrm{CCN} 3$ was induced as a direct consequence of BCR-ABL kinase activity in FDCPMix primitive hematopoietic stem cells (McCallum et al. 2006). Administration of a tyrosine kinase inhibitor (Imatinib) upregulates $\mathrm{CCN} 3$ expression and transfection of $C C N 3$ inhibits proliferation and decreases clonogenic potential of BCR-ABL (+) CML cells. From these results, it may be possible to hypothesize that CCN3 directly regulates the proliferation and differentiation of myeloid precursor cells in the niche of normal hematopoiesis. In fact, transient upregulation of $C C N 3$ is essential for the development of hematopoietic stem cells derived from the umbilical cord vein or of FDCP-Mix cells (Gupta et al. 2007). Particularly, primitive stage of hematopoietic cells (CD34 (+)) is sensitive for $\mathrm{CCN} 3$ expression. Downregulation by siRNA of $C C N 3$ abrogates their differentiation ability and upregulation of CCN3 either by $\mathrm{CCN} 3$ gene transfection or protein administration promotes their differentiation and proliferation. These investigations were done in culture in vitro of hematopoietic cells without the effect of stroma, in which self-regulation of hematopoietic cells is discussed for CCN3 expression. But it may be more possible that the neighboring cells to hematopoietic stem cells commit the regulation of $\mathrm{CCN} 3$ constructing the niche environment. In this issue, we focus on the role of CCN3 in the bone marrow environment.

\section{Materials and methods}

\section{Whole mount in situ hybridization}

See the references for the detailed information about the used probes (chicken CCN3 (Katsube et al. 2001), chicken Sonic Hedgehog (Watanabe and Nakamura 2000), chicken Serratel (Sakamoto et al. 1998)). The digoxigenin-labeled cRNA antisense and sense probes were prepared using linearized plasmid DNA according to the manufacturer's protocol (Roche Diagnostics). Embryonic stage was determined by Hamburger and Hamilton staging (Hamburger 1992). Expression of each gene was visualized with antisense probes verifying the background coloration with sense probes (negative control). Coloration was stopped before the background staining started. The chick embryos were dissected and fixed in 4\% paraformaldehyde/phosphate-buffered saline (PBS). Whole mount in situ hybridization was performed in accordance with the protocol described in the reference (Papalopulu et al. 1991). Tissue section was made with $7 \mu \mathrm{m}$ thickness after dehydration and embedding in paraffin.

\section{Expression profiling}

Mouse bone marrow derived mesenchymal stem cells were cultured with $\alpha$-modified minimum essential medium ( $\alpha$-MEM) containing 10\% fetal bovine serum (FBS). In semiconfluent stage, total RNA was extracted with Trizol (Invirogen) and approximately $1 \mu \mathrm{g}$ of total RNA was reversetranscribed to cDNA by Superscript II 
(Invitrogen). Detailed information about the analysis of genechip using cDNA is supplied by manufacturer's home page (Affymetrix, http://www.affymetrix.com/ index.affx).

\section{Anti CCN3 antibody}

Rabbit polyclonal antibody against murine CCN3 was raised by three different synthetic epitope peptides (amino acid residue position; 83-95; CDRSADPNNQTGI-coNH2, 246-260; CEQEPEEVTDKKGKK-coNH2, 334-348; CPQNNEAFLQDLELK-coNH2). These amino acid sequences are well conserved among species. Raised antisera are purified with the peptide of 334-348; CPQNNEAFLQDLELK-coNH2. In this study, preabsorption experiment of the antibody was performed with this peptide.

\section{Immunohistochemistry}

EDTA decalcified mouse adult ( 8 weeks after birth) femoral bone is embedded in paraffin. Tissue section was made by $5 \mu \mathrm{m}$ thickness. The sections are deparaffinated by xylene and hydrated in PBS. Tissue section was incubated with anti-CCN3 antibody (diluted in 1:1000) overnight at $4^{\circ} \mathrm{C}$. Antibody detection was performed by Envision rabbit antibody system. Coloration was performed with 3, 3'diaminobenzidine and nuclear counterstain was done with Hematoxylin.

\section{Western blot analysis}

The cells were lysed with TNTE buffer (100 mM Tris-Cl pH 7.6, $150 \mathrm{mM} \mathrm{NaCl,} 1 \mathrm{mM}$ EDTA, 1\% Triton X-100). The samples were boiled in Laemmli loading buffer for $2 \mathrm{~min}$, applied to $10 \% \mathrm{SDS}-\mathrm{PAGE}$, and electroblotted onto Hybond-ECL nitrocellulose membrane (Amersham Biosciences). The proteins were identified using the raised anti $\mathrm{CCN} 3$ antibody and Envision rabbit antibody system (Dako-Cytomation). The chemiluminescent imaging was performed with ECL advanced western blot detection kit (Amersham Biosciences). Anti CCN1 antibody was raised in rabbit (Mo et al. 2002). Anti CCN2 antibody was purchased (rabbit anti-CTGF, Torrey Pines Biomedical). Anti CCN3 antibody is the same as used in immunohistochemistry.

Alkaline phosphatase induction in $\mathrm{C} 2 \mathrm{C} 12$ cells in separate coculture

Kusa-A1 cells were cultured in $\alpha$-MEM containing $10 \%$ FBS. C2C12 cells were cultured in Dulbecco's modified Eagle's medium (DMEM) containing 20\% FBS. CCN3 and
CCN3 $\triangle \mathrm{CT}$ were transfected to Kusa-A1 by Flp-In system (Invitrogen) using FuGENE 6 Transfection Reagent (Roche Diagnostics). Kusa cells stably expressing CCN3 or CCN3 $\Delta \mathrm{CT}$ were selected with $200 \mu \mathrm{g} / \mathrm{ml}$ Hygromycin (WAKO) and isolated several clones with single colony isolation. C2C12 cells are inoculated into the dish at semiconfluency. Recombinant human BMP2 (Osteogenetics) was administered at $500 \mathrm{ng} / \mathrm{ml}$ for one day to initialize the osteoblastic differentiation of $\mathrm{C} 2 \mathrm{C} 12$. Then, the $\mathrm{BMP} 2$ containing culture media were removed and rinsed once with DMEM. Separate coculture started with Kusa-A1 cells using a membrane culture insert (Becton Dickinson). Separate coculture was maintained in DMEM containing $10 \%$ FBS for three days. Alkaline phosphatase (ALP) positive cells were visualized using NitroBlueTetrazolium and 5-Bromo-4-Chloro-3-Indolylphosphate-5-Toluidine salt after the fixation.

\section{Results}

Chicken CCN3 expression in embryonic and extraembryonic tissues

Expression of CCN3 in axial structure becomes visible in the presegmentation stage and reaches to the highest level at the beginning of somitogenesis ( $\mathrm{HH}$ stage 7, Fig. 1a). Strong similarity between CCN3 and Sonic Hedgehog was observed for the expression pattern in axial structure (notochord and floor plate), in which the left-right asymmetrical pattern in the node area is also conserved (Fig. 1b). However, Sonic Hedgehog expression is slightly broader than that of CCN3. Since CCN3 stimulates Notch signaling (Sakamoto et al. 2002), we investigated the expression of Notch signal genes. Among them, Serrate1, a ligand of Notch is unique because its expression is apparently a right deviated pattern in the node area (Fig. 1c). Another Notch ligand, Deltal shows a right deviated pattern, but is more caudal area of the node extending to the primitive streak (data not shown). The expression of $C C N 3$ in axial structure was followed by the presomitic mesoderm although it is diminished (Sakamoto et al. 2002).

There is accumulating evidence of $\mathrm{CCN} 3$ commitment to hematopoiesis and therefore we investigated the CCN3 expression in extraembryonic tissues. Blood islands are formed in the yolk sac mesodermal area just between the visceral endodermal and ectodermal layers, which supply the red blood cells at the primary stage. The cells in blood islands are called hemangioblasts since they also differentiate into the endothelial cells of extraembryonic blood vessel structure. In chicken embryo, differentiating endothelial cells in the ventral part of blood islands express 
Fig. 1 Expression of mRNA in early stage chicken embryo; CCN3 (a), Sonic Hedgehog (b) and Serratel (c) at the beginning stage of somitogenesis (Hamburger and Hamilton (HH) Stage 7). Arrowheads indicate Hensen's node. Demonstrates the schematic view of tissue organization at this stage (d). Expression of CCN3 mRNA in blood islands of chicken extraembryonic tissue (HH stage 10) (e). Ventral part of the endothelial precursor cells in blood islands is positive for CCN3 expression. Coloration was stopped before the background staining started in sense probes (negative control)

CCN3 from the initial stage (Fig. 1e). Erythroblasts in the center of blood islands (spherical cells in Fig. 1e) weakly express $\mathrm{CCN} 3$ and their expression is mildly enhanced in later stage (data not shown).

\section{CCN3 and mouse bone marrow cells}

The importance of bone marrow stromal cells as the niche constituent for blood stem cells has been recognized from the investigation of in vitro culture of hematopoietic cells (Harigaya 1987). The stromal cells not only give the microenvironment for the installation of hematopoietic cells, but also produce several growth factors and membrane associated proteins to maintain hematopoiesis (Haylock and Nilsson 2005). In mammals and birds, bone marrow is the main place for tertiary stage of hematopoiesis, but the precise histological locality of hematopoietic stem cells has not been identified. In hematopoietic red bone marrow, many osteoblasts and stromal cells colocalize with hematopoietic cells, and histomorphologically, little difference is observed in whole area. In 2003, two independent research groups reported the precise locality of hematopoietic stem cells(Calvi et al. 2003; Zhang et al. 2003), in which a few "osteoblastic" populations (not termed as osteoblasts) in the bone extremities (endosteal tissue near the epiphysis of long bone) are charged for the niche formation. Also, the importance of several intercellular regulatory molecules is demonstrated from these reports such as Notch1/Jag1 and N-Cadherin. CCN3 expression in bone marrow has been expected from the analysis of in vitro hematopoiesis, but genechip analyses demonstrate that bone marrow tissue is empty for $\mathrm{CCN} 3$ expression (Refer to the web site of NCBI/Unigene; http:// www.ncbi.nlm.nih.gov/ with Nov $(=\mathrm{CCN} 3))$. It has been difficult to detect the subtle expression of $\mathrm{CCN} 3$ by commercially available antibodies and we raised a new antibody in rabbit against mouse $\mathrm{CCN} 3$. We verified the specificity of this antibody by western blot analysis (Fig. 2a) using the protein extract of Kusa-A1. Raised CCN3 antibody detected two bands (major 45kd and minor $16 \mathrm{kd}$ ) while the preincubated antibody with the epitope peptide had no specific bands. This CCN3 antibody was applied to the immunohistochemistry of mouse adult bone
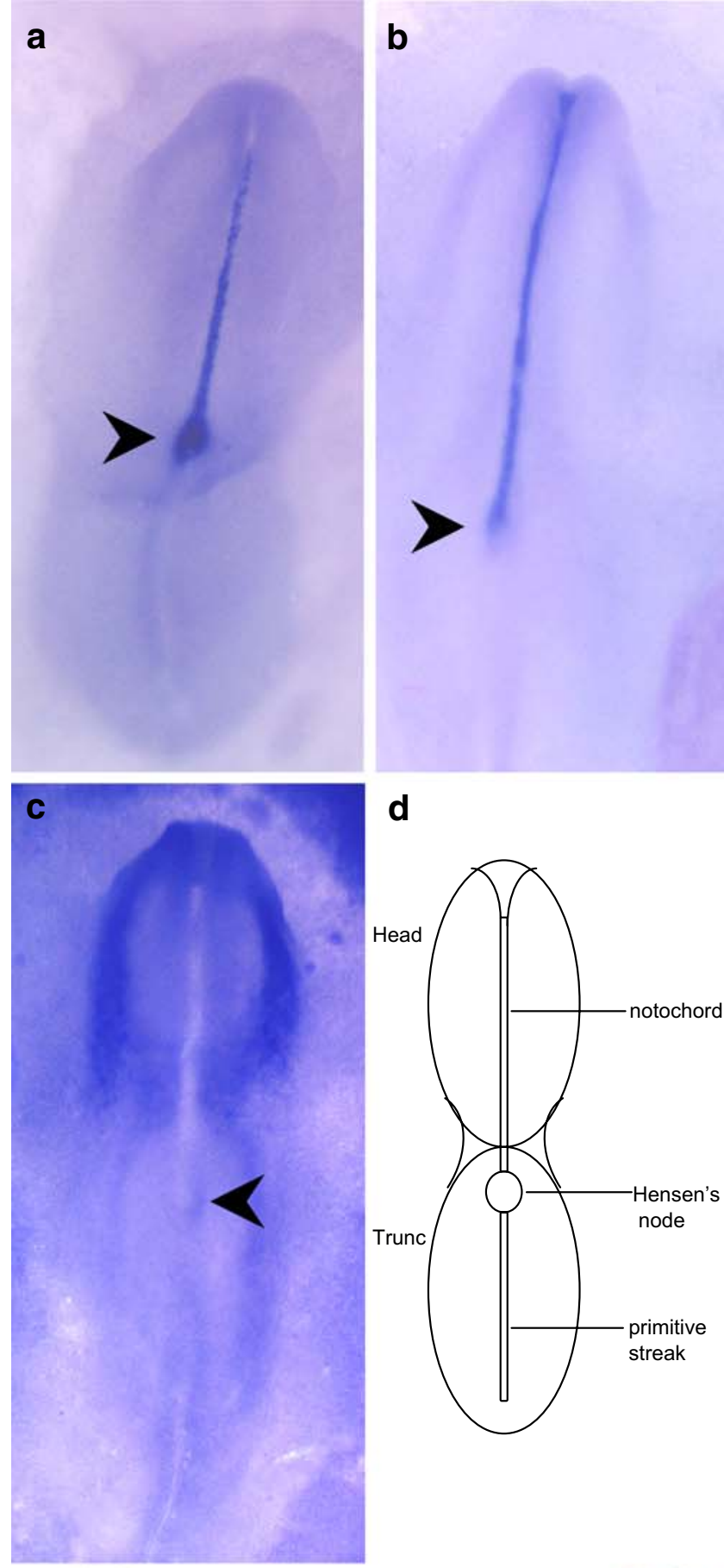

d
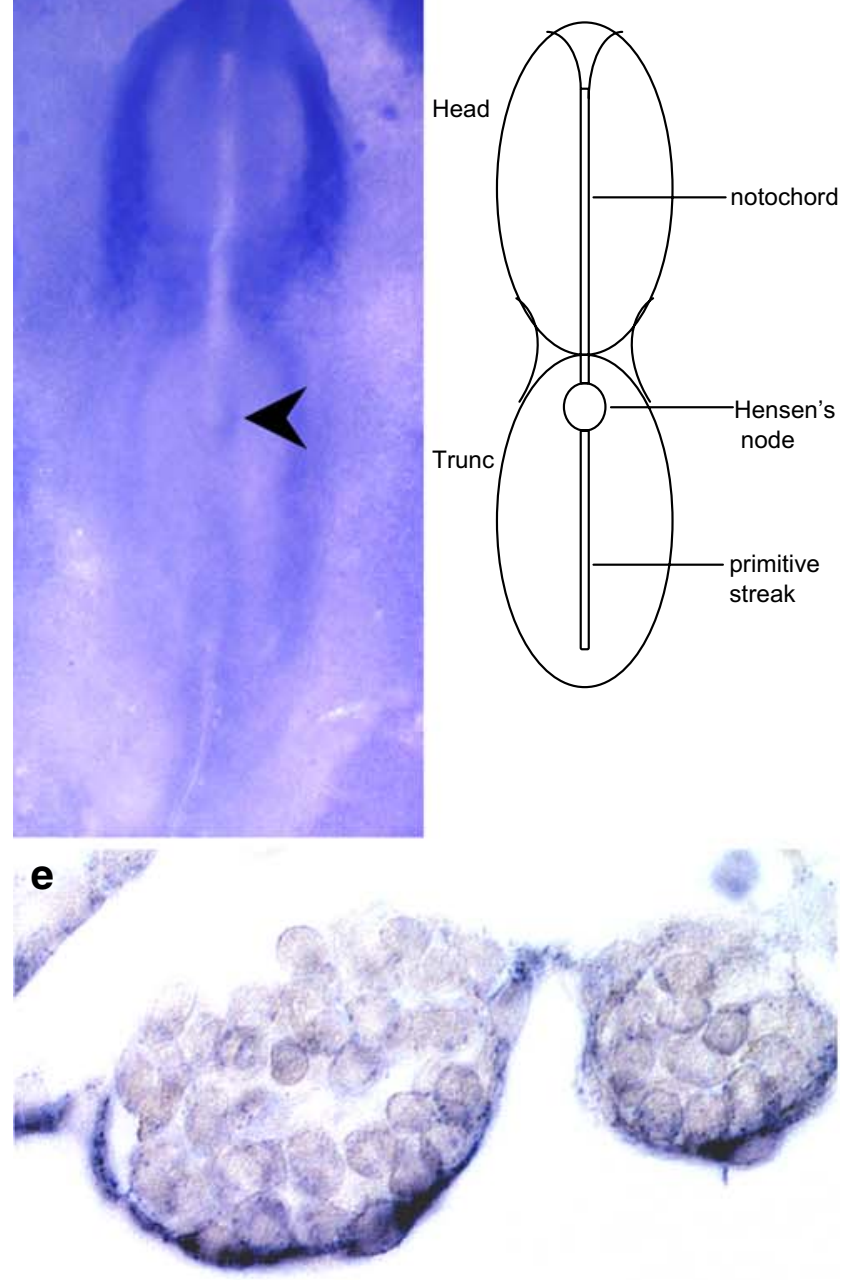
Fig. 2 Confirmation of the raised $\mathrm{CCN} 3$ antibody specificity (a) western blot analysis using CCN3 antibody. Protein extracts from Kusa-A1 were lorded and incubated with nontreated antibody or the antibody pre-incubated with the epitope peptide (b). CCN3 positive cells in mouse adult femoral bone marrow were detected with non-treated antibody (c). No positive cell is detected with the antibody preincubated with the epitope peptide
A

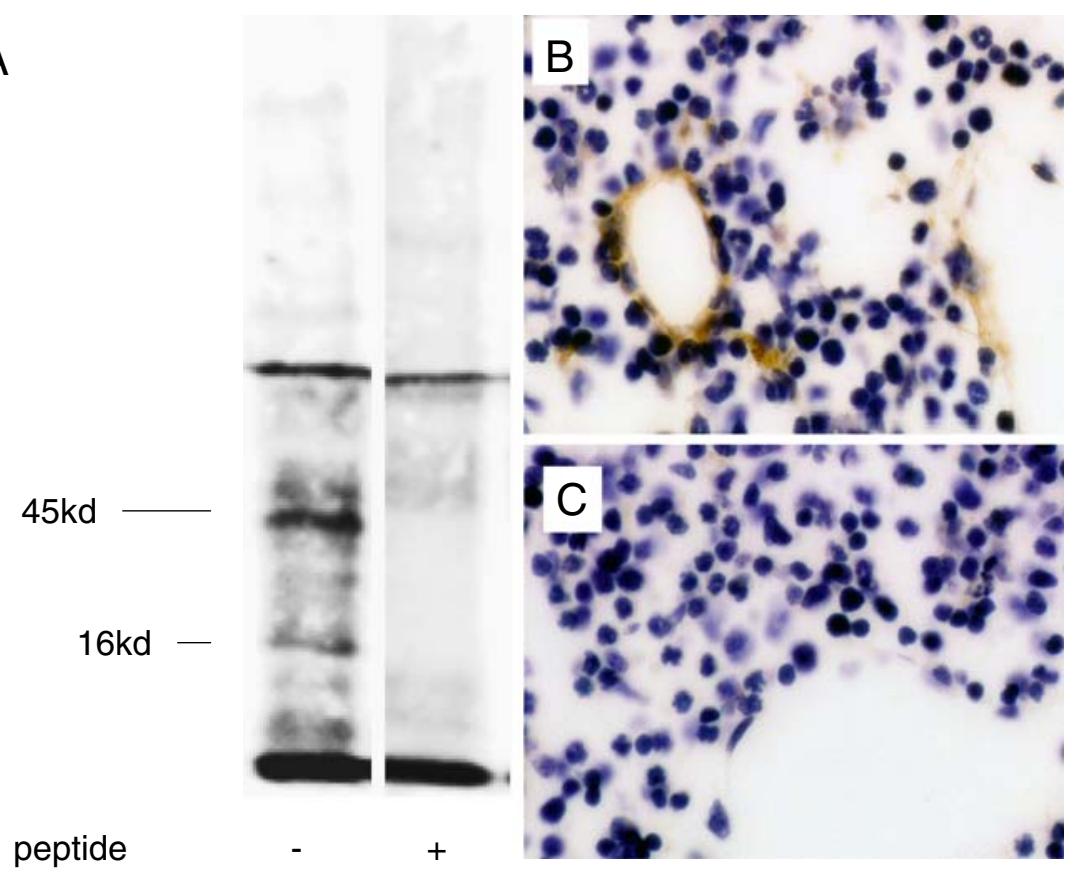

Fig. $3 \mathrm{CCN} 3$ positive cells of the bone marrow are observed in the mouse femoral bone extremities. Endothelial cells of microvascular structure are positive for CCN3. Several surrounding cells (hematopoietic and spindle-shaped stromal cells) are also positive for CCN3. On the while, diaphysis bone marrow cells are negative
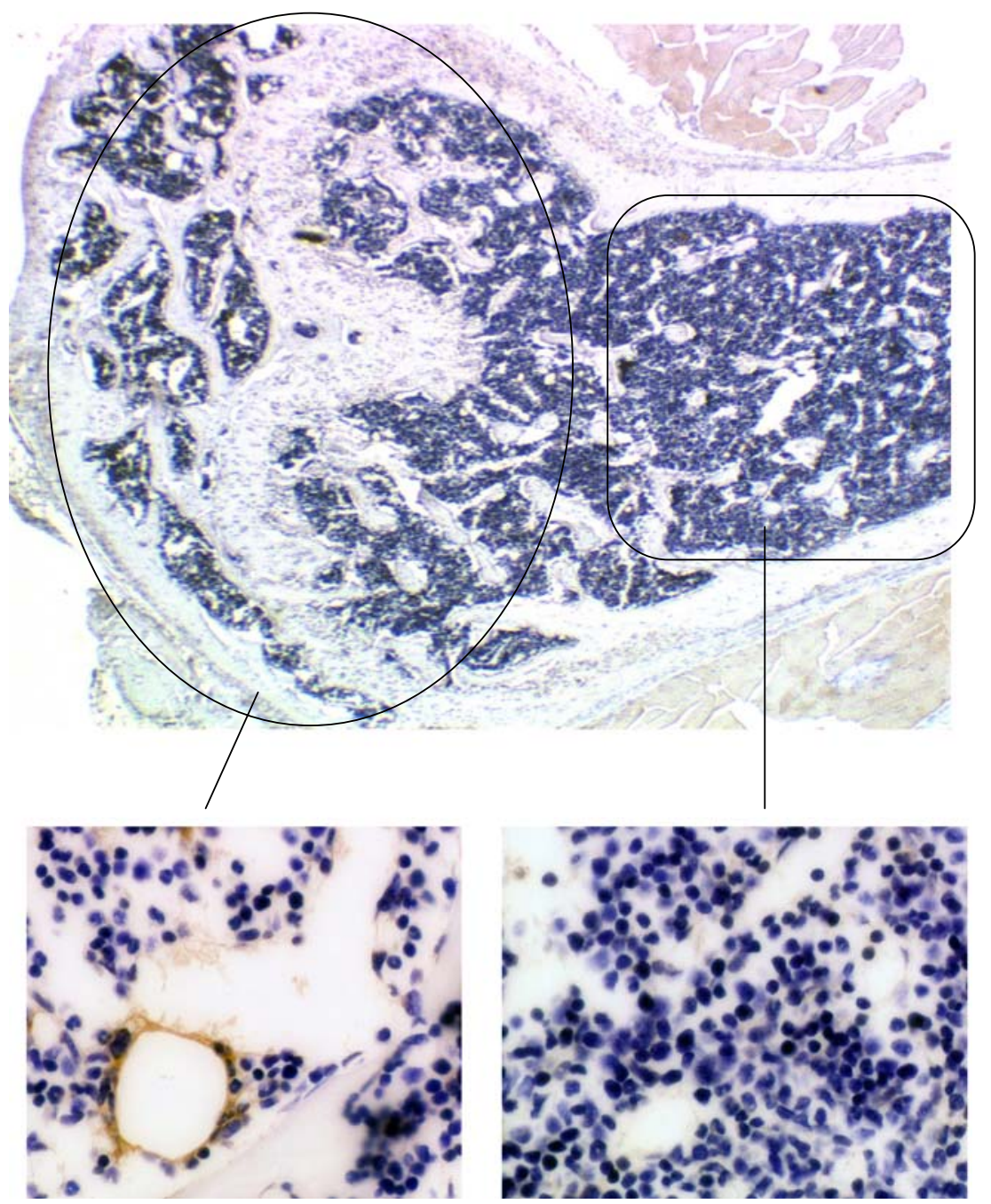
marrow tissue (Fig. 2b). Endothelial cells and several cells around the microvascular structure showed the immunoreactivity. On the while, the $\mathrm{CCN} 3$ antibody preincubated with the epitope peptide showed no positive cells (Fig. 2c). These CCN3 expressing cells exist only in the bone extremities (Fig. 3); endosteal region near the epiphysis including secondary ossifying center. Endothelial cells of small blood vessels are positively stained with $\mathrm{CCN} 3$ antibody in the bone extremities. Around these vessels, some spherical hematopoietic cells (including megakaryocytes) and polygonal or spindle-shaped stromal cells are also positive for $\mathrm{CCN} 3$. The spindle-shaped cells localized just between the trabecular bone tissue and microvascular structure. Some CCN3 positive spindle-shaped cells seem to be loosely contacted each other.

CCN3 and cultured bone marrow derived mesenchymal stem cells

To do the stable culture of hematopoietic cells, establishment of stromal cell line is indispensable. Many attempts have been done to get immortalized clones of stromal cells (Umezawa et al. 1991). During the analyses of these established cell lines, their own differentiation potential as stem cells has come to be recognized (Umezawa et al. 1992). It is not surprising that they have the potential to differentiate into osteoblasts or adipocytes since the bone marrow cavity are filled with the trabecular bone and adipose tissue in white bone marrow. But now it is known that some of the bone marrow derived mesenchymal stem cells differentiate into neurons or muscle cells, or even some endodermal cells. From the tracing analysis using genetic markers, some stromal cells in the bone marrow seem to originate from the neural crest, which may explain their pluripotency (Morikawa et al. 2009). This differentiation potential is actually highlighted from the point of view of their application to the human regeneration therapy, but in vivo, these cells are quiescent in the usual state. A few populations circulate in blood stream, which are seem to be recruited to the injured area to restitute the tissue organization. However, their proper regulatory mechanism in reorganization is still not well understood although their contribution is apparent.

Until now, a lot of clones of stem cells have been identified from the bone-marrow stromal cells. Each cell line of bone marrow stromal cells has different orientation for differentiation (Kohyama et al. 2001). We chose four independent clones of mouse stem cells and investigated their expression property of CCN family of genes by genechip analyses (Fig. 4). Examined cell lines are 9-15C, H123, Kusa-A1 and Kusa-O. 9-15C is multipotential, which includes osteogenic, chondrogenic, adipogenic, neurogenic, and cardio-myogenic differentiation (Sharov et al. 2003). H-
123 is also multipotential, but strong preference for adipogenesis (Makino et al. 1999). Kusa-A1 and Kusa-O are sister cell lines and both osteogenic (Umezawa et al. 1992). However, Kusa-A1 has much stronger potential for osteogenesis and Kusa-O has relative tendency for adipogenic differentiation (Kawashima et al. 2005; Allan et al. 2003). Kusa-A1 also possesses the ability of neuronal differentiation (Kohyama et al. 2001). Among CCN family of genes, CCN3 is highly expressed in Kusa-A1 and Kusa-O (Fig. 4c). On the while, CCN1 shows the tendency of high level expression for adipogenic orientation (Kusa-O and H-123) (Fig. 4a). Contrary to $C C N 1, C C N 2$ expression is suppressed in adipogenic orientation (H-123 and Kusa A) (Fig. 4b). It may be possible to hypothesize that $C C N 3$ expression has relatively high preference for osteogenic differentiation as compared with other $\mathrm{CCN}$ family of genes. Western blot analysis revealed that the protein level almost corresponds to the mRNA level in each cell line (Fig. 4d).

CCN3 and osteogenic ability of bone marrow derived mesenchymal stem cells

Endogenous CCN3 expression in Kusa-A1 is high in the default state and moderately downregulated during the induction of mineralization (Kawashima et al. 2005). It is noteworthy that a relatively low osteogenic cell line of Kusa, Kusa-O maintains the continuous high expression of CCN3 (Kawashima et al. 2005). Therefore we investigated the role of CCN3 in Kusa-A1 (Katsuki et al. 2008). For this purpose, we created several deletion mutants of CCN3 to investigate its role from the aspect of Notch signal. CT domain binds to Notch extracellular domain and is indispensable for the Notch signal activation.

Constitutive expression of CCN3 significantly downregulated osteogenesis of Kusa-A1, but did not affect its neurogenesis. Anti-osteogenic activity of $\mathrm{CCN} 3$ was reduced by the deletion of the CT domain. This deletion abrogates the upregulation of authentic Notch signal downstream targets, Hes1 and particularly, Heyl. We also demonstrated that $\mathrm{CCN} 3$ could downregulate cell proliferation of Kusa-A1. We found a specific upregulation of $\mathrm{p} 21$ among several cell cycle regulators and confirmed that deletion of $\mathrm{CT}$ domain from $\mathrm{CCN} 3$ could cancel p21 upregulation, which suggests that $\mathrm{CCN} 3$ upregulates $\mathrm{p} 21$ through Notch signaling. In fact, inhibition of Notch signal by gamma secretase inhibitor also downregulated the CCN3 effect on p21 upregulation, strongly suggesting CCN3 mainly employs Notch signal for p21 upregulation. This finding is interesting from the point of view of the Notch signal because $\mathrm{p} 21$ activation by Notch was reported mainly in epithelial cells (Rangarajan et al. 2001). CCN3 seem to put default Kusa-A1 in a quiescent state suppressing both osteogenesis and proliferation (Figs. 4 and 5). 
Fig. 4 Expression profile of CCN1 (a), CCN2 (b), and CCN3 (c) mRNAs in four different mouse bone marrow derived mesenchymal stem cell lines. Top (1): 9-15c, right (2): Kusa-O bottom (3): Kusa-A1, left (4): H-123. Normalization of relative expression level was done by the comparison with a set of house keeping genes in the genechip of Affymetrix. All quantitative analyses were done by Affymetrix Gene Spring with normalization with several house-keeping genes. (d) Western blot analysis with antiCCN1, CCN2 and CCN3. 1: Kusa-A1, 2: Kusa-O, 3: 9-15C, 4: H-123, 5; MC3T3-E1

\section{a}

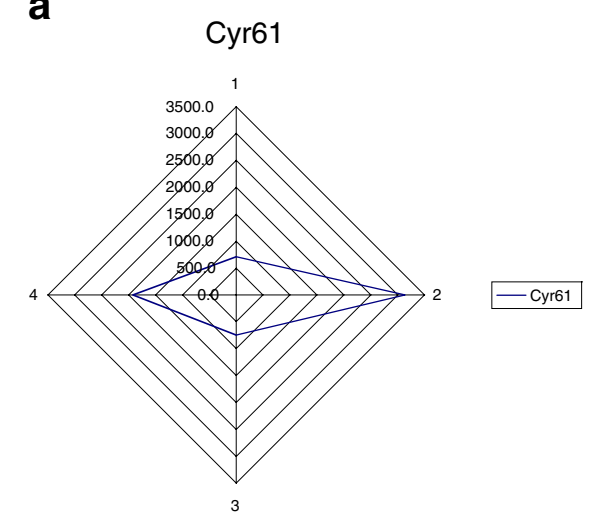

b

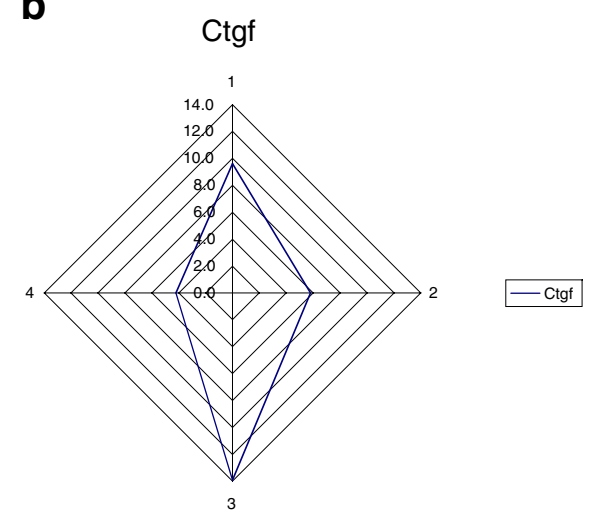

C
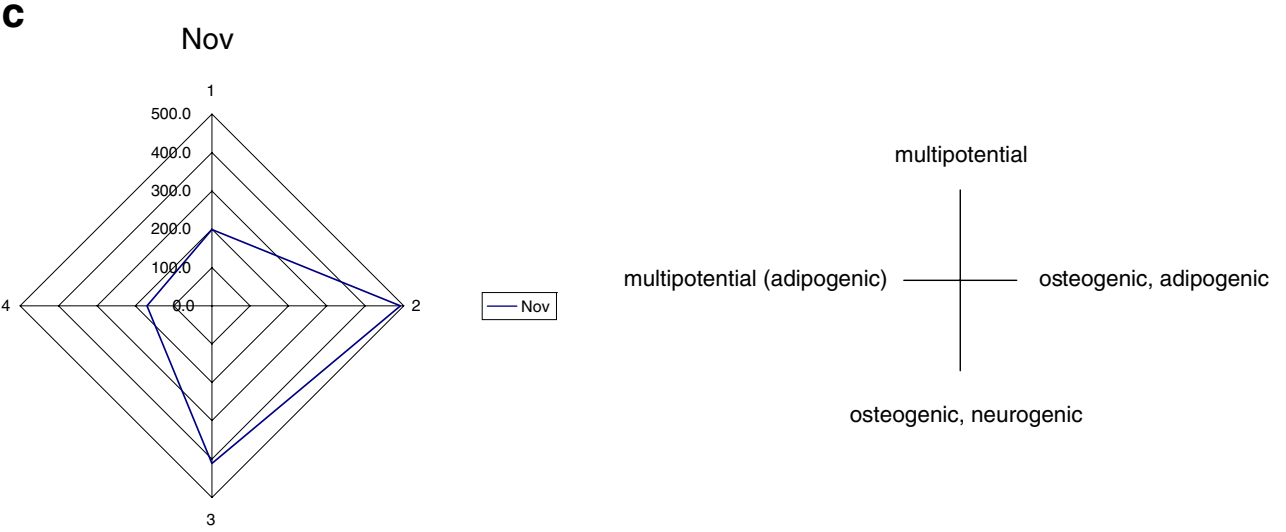

osteogenic, neurogenic

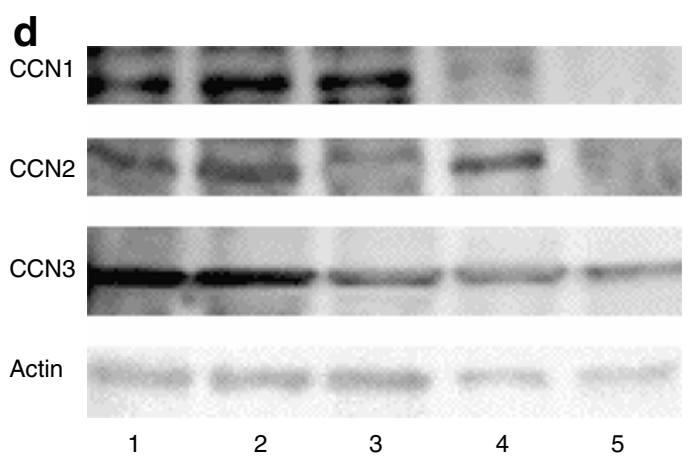

The role of $\mathrm{CCN} 3$ in the microenvironment of bone marrow is still not clear. The anti-osteogenetic ability of CCN3 in osteoblast cell lines are demonstrated in vitro culture (Minamizato et al. 2007; Parisi et al. 2006; Rydziel et al. 2007), but CCN3 expression is under detectable in most of the osteoblasts in vivo (Fig. 3). And also there has been an argument that interaction of $\mathrm{CCN} 3$ with the relating molecules is an intracellular event or an extracellular event (cell-autonomous or non autonomous). It may be possible that $\mathrm{CCN} 3$ is not expressed by osteoblasts themselves but by other surrounding cells such as stromal cells. To clarify these matters, we tried the separate coculture experiment using Kusa-A1 and $\mathrm{C} 2 \mathrm{C} 12$ that was initiated into osteoblastic differentiation (Fig. 6a). The induction of alkaline phosphatase (ALP) in $\mathrm{C} 2 \mathrm{C} 12$ was inhibited by secreted CCN3 from Kusa-A1 (Fig. 6b). Kusa-LacZ transfected with full length $\mathrm{CCN} 3$ by Flp-In vector clearly reduced the number of ALP positive cells. On the while, Kusa-LacZ transfected with $\mathrm{CT}$ deleted $\mathrm{CCN} 3$ moderately reduced the number of ALP positive cells. These results indicate that anti-osteogenetic activity of CCN3 is intercellularly mediated probably by Notch stimulation and BMP suppression. 
CCN3 effect in osteogenic bone marrow derived stem cells

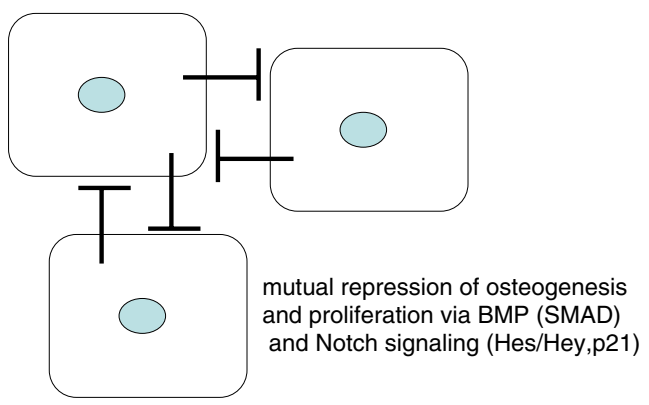

Fig. 5 Osteogenic mesenchymal stem cells negatively regulate osteogenesis and proliferation by $\mathrm{CCN} 3$

\section{Discussion}

CCN3 expression is detected from the early stage of embryogenesis including the hematopoiesis in the extraembryonic tissue. Its expression in the ventral part of blood islands is interesting because visceral endodermal cells of yolk sac are considered to be essential for hemangiogenesis

a

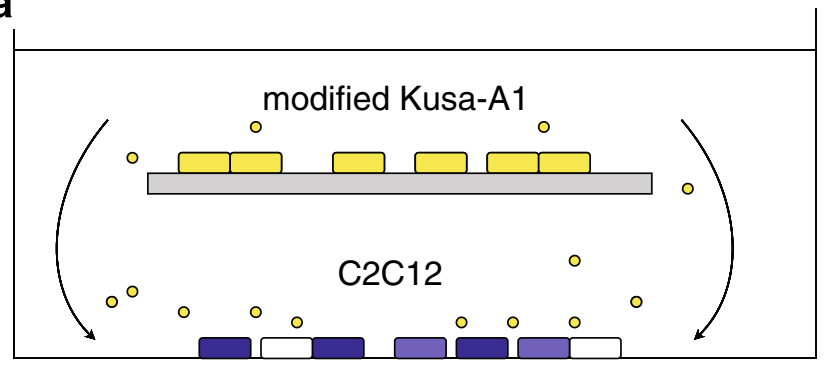

b

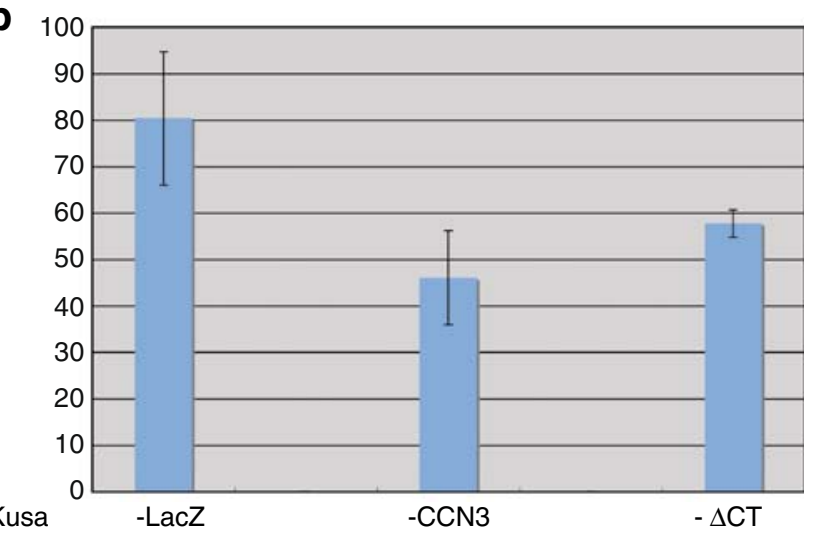

Fig. $6 \mathrm{CCN} 3$ functions as a secreting inhibitor in alkaline phosphatase (ALP) induction ofC2C12 cells. a Schematic view of the separate coculture experiment. Kusa-A1 and $\mathrm{C} 2 \mathrm{C} 12$ cells were cultured in the same dish, but separated by a thin membrane insert (Culture separate, Becton Dickinson). The medium freely circulates, but no direct contact between two separate cultures. b Effect of Kusa cells stably transfected with $\mathrm{CCN} 3$ and its deleted form is measured by counting ALP positive cells in $\mathrm{C} 2 \mathrm{C} 12$ (cells $/ 0.01 \mathrm{~mm}^{2}$ ) (angiogenetic cell clustering), secreting Indian Hedgehog (Byrd et al. 2002) and VEGF (Caprioli et al. 2001). Indian Hedgehog expression is also observed in mesodermal cells between visceral endoderm and embryonic ectoderm (Grabel et al. 1998). High similarity in spatial distribution pattern between CCN3 and the Hedgehog family gene is also observed in Hensen's node. Preliminary experiment using the bead carrying recombinant CCN3 protein demonstrated that CCN3 upregulates Sonic Hedgehog in the nodal area (data not shown) during gastrulation. This indicates that there exists the direct interaction for the coexpression of CCN3 and Hedgehog gene family. Serrate1 expression in Hensen's node is also interesting because expression of Jag1, the murine equivalent of Serrate1 is similar to that of CCN3 in bone marrow. We do not know the significance of the mirror-imaged symmetrical expression pattern of CCN3 and Serrate1 in the node, but Notch signal is reported to participate in left-right asymmetry under the influence of calcium signal (Raya et al. 2003).

In adult mouse, a very few populations exhibit $\mathrm{CCN} 3$ expression in the extremity of bone marrow, whose area is responsible for the stem cell niche of hematopoietic cells. Previous investigations by gene chip analysis all failed to detect $\mathrm{CCN} 3$ expression in bone marrow, but it may be due to the limited locality of $\mathrm{CCN} 3$ positive cells (Bone extremities are usually cut off to elute the bone marrow cells.). As mentioned, distribution of $\mathrm{CCN} 3$ positive cells in bone marrow is rather similar to that of Jag1 (=murine Serrate1) positive cells although CCN3 positive cells are much limited. CCN2 (CTGF) expression is previously

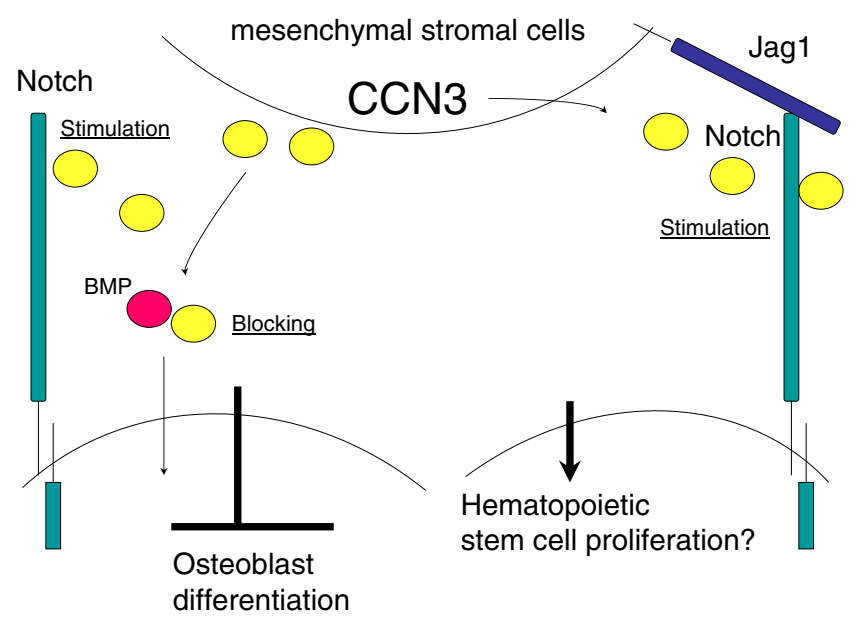

Fig. 7 Scheme of a hypothetical role of CCN3 in the bone marrow niche. CCN3 (yellow) suppresses the BMP (red) activity by direct binding. On the while, $\mathrm{CCN} 3$ binds to Notch receptor, which results in the signal stimulation. Notch signal stimulation is principal for the maintenance of stem cell property, blocking the terminal differentiation. $\mathrm{CCN} 3$ secreted by stromal stem cells modulates the growth and differentiation of neighboring osteoblasts and hematopoietic stem cells 
reported in the chondrocytes near the secondary ossifying center (Oka et al. 2007), but there is no report about the expression of $\mathrm{CCN}$ family of genes in the secondary ossifying center itself.

As for cultured bone marrow-derived mesenchymal stem cells, CCN3 expression is highly maintained in the default state of an osteogenic cell line, Kusa-A1. In human bone marrow derived stem cells, the expression level of $\mathrm{CCN}$ family was examined with regard to several orientation of differentiation (adipogenesis, osteogenesis, chondrogenesis) (Schutze et al. 2005). From their investigation, CCN3 expression is not detectable, but high expression of $\mathrm{CCN} 1$ and $\mathrm{CCN} 2$ was observed in the default state. Their expression was downregulated in the course of differentiation, but there is no particular correlation with differentiation orientation. Direct evidence about the role of $\mathrm{CCN}$ in the human mesenchymal stem cells is not confirmed from their investigation, but it is hypothesized that $\mathrm{CCN}$ is a negative regulator of differentiation. Another report demonstrated that the induction of hepatocyte-like cells from human bone marrow derived stem cells downregulated CCN4 and CCN5 expression (Shimomura et al. 2007) while no significant change is observed in $\mathrm{CCN} 1, \mathrm{CCN} 2$ and CCN3. They tried downregulation of CCN4 or CCN5 by siRNA, which resulted in the promotion of the hepatocyte-like differentiation. We observed that KusaA1 downregulated endogenous $\mathrm{CCN} 3$ expression after the induction of mineralization while low osteogenic Kusa-O continuously upregulates $\mathrm{CCN} 3$ even after the treatment (Kawashima et al. 2005). Continuous CCN3 upregulation in Kusa-A1 downregulated the osteogenesis, but did not touch its neurogenic potency (Katsuki et al. 2008). These facts may indicate the CCN3 specifically affects the osteogenic differentiation in murine bone marrow mesenchymal stem cells.

It may be intriguing to hypothesize that Kusa-A1 is a core descendent of stem cell niche constituents of hematopoiesis because the stromal cells of hematopoietic niche are "osteoblastic" (Calvi et al. 2003). Interaction of bone marrow stromal cells with hematopoietic cells is critical as they regulate the microenvironment of niche and maintain the stemness and homing of hematopoietic stem cells. From this point of view, $\mathrm{p} 21$ upregulation by $\mathrm{CCN} 3$ is interesting. p21 is important not only for cell proliferation, but also terminal differentiation of mesenchymal stem cells (van den Bos et al. 1998). Also, stem cell maintenance of PML-RAR activated hematopoietic cells requires p21 to prevent DNA damage and excess proliferation (Viale et al. 2009). Recent investigation of bone marrow niche demonstrates that hematopoietic stem cells dynamically change their locality with differentiation (Lo Celso et al. 2009). CCN3 may regulate these complicated behaviors since it also affects cell attachment and migration (Fukunaga-Kalabis et al. 2008). CCN3 expression suppresses not only the selfosteogenic activity, but also the osteoblasts in separate culture. This paracrine manner of CCN3 expression may supply the bone cavity space enough to reside the niche environment of hematopoiesis. The verification of the effect of $\mathrm{CCN} 3$ in adult bone marrow would provide a new way of thinking about hematopoiesis (Fig. 7). Analyses using knockout mice of $\mathrm{CCN} 3$ are really necessary to give an answer about this question.

Acknowledgement This work was supported by Grant-in-Aid for Scientific Research from the Japan Society for the Promotion of Science to KK (15390552 and 20592135). KK, ST and AU are supported by Grant-in-Aid from the Japanese Ministry of Health, Labor and Welfare (19A-7, Nervous and Mental Disorders).

Open Access This article is distributed under the terms of the Creative Commons Attribution Noncommercial License which permits any noncommercial use, distribution, and reproduction in any medium, provided the original author(s) and source are credited.

\section{References}

Allan EH, Ho PW, Umezawa A, Hata J, Makishima F, Gillespie MT, Martin TJ (2003) Differentiation potential of a mouse bone marrow stromal cell line. J Cell Biochem 90(1):158-169

Brigstock DR, Goldschmeding R, Katsube KI, Lam SC, Lau LF, Lyons K, Naus C, Perbal B, Riser B, Takigawa M, Yeger H (2003) Proposal for a unified CCN nomenclature. Mol Pathol 56 (2): $127-128$

Byrd N, Becker S, Maye P, Narasimhaiah R, St-Jacques B, Zhang X, McMahon J, McMahon A, Grabel L (2002) Hedgehog is required for murine yolk sac angiogenesis. Development 129 (2):361-372

Calvi LM, Adams GB, Weibrecht KW, Weber JM, Olson DP, Knight MC, Martin RP, Schipani E, Divieti P, Bringhurst FR, Milner LA, Kronenberg HM, Scadden DT (2003) Osteoblastic cells regulate the haematopoietic stem cell niche. Nature 425(6960):841-846

Caprioli A, Minko K, Drevon C, Eichmann A, Dieterlen-Lievre F, Jaffredo T (2001) Hemangioblast commitment in the avian allantois: cellular and molecular aspects. Dev Biol 238(1):64-78

Chiou MJ, Chao TT, Wu JL, Kuo CM, Chen JY (2006) The physiological role of $\mathrm{CTGF} / \mathrm{CCN} 2$ in zebrafish notochond development and biological analysis of the proximal promoter region. Biochem Biophys Res Commun 349(2):750-758

Erwin WM (2008) The Notochord, Notochordal cell and CTGF/CCN2: ongoing activity from development through maturation. J Cell Commun Signal 2(3-4):59-65

Fukunaga-Kalabis M, Martinez G, Telson SM, Liu ZJ, Balint K, Juhasz I, Elder DE, Perbal B, Herlyn M (2008) Downregulation of $\mathrm{CCN} 3$ expression as a potential mechanism for melanoma progression. Oncogene 27(18):2552-2560

Grabel L, Becker S, Lock L, Maye P, Zanders T (1998) Using EC and ES cell culture to study early development: recent observations on Indian hedgehog and Bmps. Int J Dev Biol 42(7):917-925

Gupta R, Hong D, Iborra F, Sarno S, Enver T (2007) NOV (CCN3) functions as a regulator of human hematopoietic stem or progenitor cells. Science 316(5824):590-593

Hamburger V (1992) The stage series of the chick embryo. Dev Dyn 195(4):273-275

Harigaya K (1987) Fibrocytic bone marrow stromal cells and hematopoiesis. Nippon Ketsueki Gakkai Zasshi 50(8):1499-1509 
Haylock DN, Nilsson SK (2005) Stem cell regulation by the hematopoietic stem cell niche. Cell Cycle 4(10):1353-1355

Heath E, Tahri D, Andermarcher E, Schofield P, Fleming S, Boulter CA (2008) Abnormal skeletal and cardiac development, cardiomyopathy, muscle atrophy and cataracts in mice with a targeted disruption of the Nov (Ccn3) gene. BMC Dev Biol 8(1):18

Ivkovic S, Yoon BS, Popoff SN, Safadi FF, Libuda DE, Stephenson RC, Daluiski A, Lyons KM (2003) Connective tissue growth factor coordinates chondrogenesis and angiogenesis during skeletal development. Development 130(12):2779-2791

Katsube K, Chuai ML, Liu YC, Kabasawa Y, Takagi M, Perbal B, Sakamoto K (2001) The expression of chicken NOV, a member of the CCN gene family, in early stage development. Brain Res Gene Expr Patterns 1(1):61-65

Katsube K, Sakamoto K, Tamamura Y, Yamaguchi A (2009) Role of $\mathrm{CCN}$, a vertebrate specific gene family, in development. Dev Growth Differ 51(1):55-67

Katsuki Y, Sakamoto K, Minamizato T, Makino H, Umezawa A, Ikeda MA, Perbal B, Amagasa T, Yamaguchi A, Katsube K (2008) Inhibitory effect of CT domain of CCN3/NOV on proliferation and differentiation of osteogenic mesenchymal stem cells, Kusa-A1. Biochem Biophys Res Commun 368 (3):808-814

Kawashima N, Shindo K, Sakamoto K, Kondo H, Umezawa A, Kasugai S, Perbal B, Suda H, Takagi M, Katsube K (2005) Molecular and cell biological properties of mouse osteogenic mesenchymal progenitor cells, Kusa. J Bone Miner Metab 23 (2):123-133

Kohyama J, Abe H, Shimazaki T, Koizumi A, Nakashima K, Gojo S, Taga T, Okano H, Hata J, Umezawa A (2001) Brain from bone: efficient "meta-differentiation" of marrow stroma-derived mature osteoblasts to neurons with Noggin or a demethylating agent. Differentiation 68(4-5):235-244

Lo Celso C, Fleming HE, Wu JW, Zhao CX, Miake-Lye S, Fujisaki J, Cote D, Rowe DW, Lin CP, Scadden DT (2009) Live-animal tracking of individual haematopoietic stem/progenitor cells in their niche. Nature 457(7225):92-96

Makino S, Fukuda K, Miyoshi S, Konishi F, Kodama H, Pan J, Sano M, Takahashi T, Hori S, Abe H, Hata J, Umezawa A, Ogawa S (1999) Cardiomyocytes can be generated from marrow stromal cells in vitro. J Clin Invest 103(5):697-705

McCallum L, Price S, Planque N, Perbal B, Pierce A, Whetton AD, Irvine AE (2006) A novel mechanism for BCR-ABL action: stimulated secretion of $\mathrm{CCN} 3$ is involved in growth and differentiation regulation. Blood 108(5):1716-1723

Minamizato T, Sakamoto K, Liu T, Kokubo H, Katsube K, Perbal B, Nakamura S, Yamaguchi A (2007) CCN3/NOV inhibits BMP-2induced osteoblast differentiation by interacting with BMP and Notch signaling pathways. Biochem Biophys Res Commun 354 (2):567-573

Mo FE, Muntean AG, Chen CC, Stolz DB, Watkins SC, Lau LF (2002) CYR61 (CCN1) is essential for placental development and vascular integrity. Mol Cell Biol 22(24):8709-8720

Morikawa S, Mabuchi Y, Niibe K, Suzuki S, Nagoshi N, Sunabori T, Shimmura S, Nagai Y, Nakagawa T, Okano H, Matsuzaki Y (2009) Development of mesenchymal stem cells partially originate from the neural crest. Biochem Biophys Res Commun 379(4):1114-1119

Oka M, Kubota S, Kondo S, Eguchi T, Kuroda C, Kawata K, Minagi S, Takigawa M (2007) Gene expression and distribution of connective tissue growth factor (CCN2/CTGF) during secondary ossification center formation. J Histochem Cytochem 55 (12): $1245-1255$

Papalopulu N, Clarke JD, Bradley L, Wilkinson D, Krumlauf R, Holder N (1991) Retinoic acid causes abnormal development and segmental patterning of the anterior hindbrain in Xenopus embryos. Development 113(4):1145-1158

Parisi MS, Gazzerro E, Rydziel S, Canalis E (2006) Expression and regulation of CCN genes in murine osteoblasts. Bone 38(5):671677

Perbal B (2007) CCN3-mutant mice are distinct from CCN3-null mice. J Cell Commun Signal 1(3-4):229-230

Rangarajan A, Talora C, Okuyama R, Nicolas M, Mammucari C, Oh H, Aster JC, Krishna S, Metzger D, Chambon P, Miele L, Aguet M, Radtke F, Dotto GP (2001) Notch signaling is a direct determinant of keratinocyte growth arrest and entry into differentiation. Embo J 20(13):3427-3436

Raya A, Kawakami Y, Rodriguez-Esteban C, Buscher D, Koth CM, Itoh T, Morita M, Raya RM, Dubova I, Bessa JG, de la Pompa JL, Belmonte JC (2003) Notch activity induces Nodal expression and mediates the establishment of left-right asymmetry in vertebrate embryos. Genes Dev 17(10):1213-1218

Rydziel S, Stadmeyer L, Zanotti S, Durant D, Smerdel-Ramoya A, Canalis E (2007) Nephroblastoma overexpressed (Nov) inhibits osteoblastogenesis and causes osteopenia. J Biol Chem 282 (27):19762-19772

Sakamoto K, Nakamura H, Takagi M, Takeda S, Katsube K (1998) Ectopic expression of lunatic Fringe leads to downregulation of Serrate-1 in the developing chick neural tube; analysis using in ovo electroporation transfection technique. FEBS Lett 426 (3):337-341

Sakamoto K, Yamaguchi S, Ando R, Miyawaki A, Kabasawa Y, Takagi M, Li CL, Perbal B, Katsube K (2002) The nephroblastoma overexpressed gene (NOV/ccn3) protein associates with Notch1 extracellular domain and inhibits myoblast differentiation via Notch signaling pathway. J Biol Chem 277 (33):29399-29405

Schutze N, Noth U, Schneidereit J, Hendrich C, Jakob F (2005) Differential expression of $\mathrm{CCN}$-family members in primary human bone marrow-derived mesenchymal stem cells during osteogenic, chondrogenic and adipogenic differentiation. Cell Commun Signal 3(1):5

Sharov AA, Piao Y, Matoba R, Dudekula DB, Qian Y, VanBuren V, Falco G, Martin PR, Stagg CA, Bassey UC, Wang Y, Carter MG, Hamatani T, Aiba K, Akutsu H, Sharova L, Tanaka TS, Kimber WL, Yoshikawa T, Jaradat SA, Pantano S, Nagaraja R, Boheler KR, Taub D, Hodes RJ, Longo DL, Schlessinger D, Keller J, Klotz E, Kelsoe G, Umezawa A, Vescovi AL, Rossant J, Kunath T, Hogan BL, Curci A, D'Urso M, Kelso J, Hide W, Ko MS (2003) Transcriptome analysis of mouse stem cells and early embryos. PLoS Biol 1(3):E74

Shimomura T, Yoshida Y, Sakabe T, Ishii K, Gonda K, Murai R, Takubo K, Tsuchiya H, Hoshikawa Y, Kurimasa A, Hisatome I, Uyama T, Umezawa A, Shiota G (2007) Hepatic differentiation of human bone marrow-derived UE7T-13 cells: effects of cytokines and $\mathrm{CCN}$ family gene expression. Hepatol Res 37 (12):1068-1079

Soret J, Dambrine G, Perbal B (1989) Induction of nephroblastoma by myeloblastosis-associated virus type 1: state of proviral DNAs in tumor cells. J Virol 63(4):1803-1807

Umezawa A, Tachibana K, Harigaya K, Kusakari S, Kato S, Watanabe Y, Takano T (1991) Colony-stimulating factor 1 expression is down-regulated during the adipocyte differentiation of $\mathrm{H}-1 / \mathrm{A}$ marrow stromal cells and induced by cachectin/tumor necrosis factor. Mol Cell Biol 11(2):920-927

Umezawa A, Maruyama T, Segawa K, Shadduck RK, Waheed A, Hata J (1992) Multipotent marrow stromal cell line is able to induce hematopoiesis in vivo. J Cell Physiol 151(1):197-205

van den Bos C, Silverstetter S, Murphy M, Connolly T (1998) p21 (cip1) rescues human mesenchymal stem cells from apoptosis 
induced by low-density culture. Cell Tissue Res 293(3): 463-470

Viale A, De Franco F, Orleth A, Cambiaghi V, Giuliani V, Bossi D, Ronchini C, Ronzoni S, Muradore I, Monestiroli S, Gobbi A, Alcalay M, Minucci S, Pelicci PG (2009) Cell-cycle restriction limits DNA damage and maintains self-renewal of leukaemia stem cells. Nature 457(7225):51-56
Watanabe Y, Nakamura H (2000) Control of chick tectum territory along dorsoventral axis by Sonic hedgehog. Development 127 (5):1131-1140

Zhang J, Niu C, Ye L, Huang H, He X, Tong WG, Ross J, Haug J, Johnson T, Feng JQ, Harris S, Wiedemann LM, Mishina Y, Li L (2003) Identification of the haematopoietic stem cell niche and control of the niche size. Nature 425(6960):836-841 